\title{
LA LENGUA LITERARIA DE PEDRO SALINAS
}

\author{
M. ${ }^{a}$ Luisa Peces
}

\section{EL POETA Y EL LENGUAJE}

«Sólo el artista de intensa fantasía es capaz de crear la expresión que traduzca, sin falsearla, la originalidad de su mención psíquica. Por eso se emancipa, cuando es preciso, de su comunidad lingüística; pasa por encima o por debajo de las palabras, mediante notas, melodías, ritmos, colores, etc.» (Salinas, 1984²: 244). En estas palabras del filólogo Vossler, Pedro Salinas quería encontrar un testimonio desinteresado que describiera la relación del poeta con su lengua. El lenguaje reúne capacidades que provocan la maravillada defensa de Salinas: la construcción del pensamiento y la comunicación. Pero es la lengua escrita la que puede hacer cumplir las ambiciones más hondas del ser humano: la sed de crear y la de perdurar («en el lenguaje el hombre [...] se vive [...] se retrovive [...] se sobrevive»). Si en el lenguaje están contenidas todas las potencialidades de expresión de lo humano, el poeta tiene en él atribuciones de soberano: porque ensancha las posibilidades del lenguaje vivo en grado sumo, puede renovar el espíritu del lenguaje, y revela a los demás la anchura del idioma. 
La lengua en manos del poeta cae en la esencia misma del arte: descubrir. Es claro que el escritor no puede soltarse de todas las cuerdas que sujetan una lengua y entregarse totalmente a un código distinto y personal, pues daría en la incomunicación. Novedad y tradición están en el lenguaje y en el arte, y de esta manera también la literatura es siempre secuencia, hasta en aquellos que quieren romper con todo.

Estas afirmaciones vertidas en los ensayos de El defensor vuelven a repetirse en varios lugares de la obra crítica de Salinas. Así, al comentar un poema de Unamuno, sentencia: «Misterio de la poesía, encerrado dentro del misterio de la lengua». El poeta saca a la vida todas las plantas que puede de entre «esos encantados vergeles que sólo él vislumbra porque crecen muy ahondados, bajo todas las capas de las potencias y funciones del lenguaje (Salinas, 1983, III: 254-255).

Ante la situación del idioma español en Puerto Rico Salinas hace una llamada a la responsabilidad de los hablantes y se muestra contrario a los postulados positivistas, según los cuales la vida de las lenguas escapaba de la influencia de la acción voluntaria del hombre. Sin embargo, su militancia en la reacción al positivismo no es circunstancial: muy clara resulta la huella de la escuela de Menéndez Pidal, así como la defensa del idealismo de Croce y Karl Vossler. Bastaría tener en mente sus ideas acerca de la tradición, la creencia en los caracteres permenentes de la literatura nacional ${ }^{1}$, o su concepción del cambio lingüístico. Por ejemplo, el poeta está convencido de que las innovaciones de la lengua literaria pueden pasar a la lengua corriente y renovarla.

El que pretenda un acercamiento a la lengua literaria de Salinas está avisado por el propio autor de que sólo rozará uno de los elementos circundantes de la poesía ${ }^{2}$. Porque, si no bastan las ideas para hacer un poema, tampoco se trata sólo de palabras: «hay que contar, en poesía más que en nada, con esa fuerza latente y misteriosa acumulada en la palabra, debajo, disfrazada de palabra, contenida, pero explosiva» (Ibid.: 379).

Quien dedicó tantas explicaciones a la literatura, con algunos ejemplos de análisis considerados por la crítica como obras cumbres de la

1 «A fuerza de leer, y comentar en clase, se me ha metido en la cabeza que hay cierto factor esencial en nuestras letras, y que cabría explicarlo desde mi punto de vista» (A. Soria Olmedo, 1992: 444).

2 Ya lo había dicho en unas palabras acerca de su poética a la cabeza de los poemas colectados para la Antología de Gerardo Diego en 1932: «Todo comentario a una poesía se refiere a elementos circundantes de ella, estilo, lenguaje, sentimientos, aspiración, pero no a la poesía misma» (G. Diego, 1991: 379). 
estilística española en los años cuarenta, se muestra contrario a la Ciencia en el terrero del estilo, y así se lo manifiesta a Guillén:

Sucede que el descubrimiento de todos esos esquemas estilísticos, de esos tópicos, como dice el otro, Curtius, por interesante que sea no toca jamás a la entraña del fenómeno poético... Sigo creyendo que a esa esencia no se llega por escalerillas de tópicos, ni de fuentes, o lo que supera la mecánica de un recurso estilístico... Siento cierta sensación de pena al pensar en que Dámaso, con su tremenda inteligencia y su sensibilidad, se ha pasado meses y meses, en la averiguación de minucias..., para dar, al cabo, con un tranquillo que usan ciertos poetas - cuando lo hacen conscientemente, por artificio- o por obediencia a una tendencia de la lengua poética, que otros como Unamuno o Bécquer perciben y usan por fidelidad a los mandatos, a la corriente de esa lengua... Muy bien que cada Garcilaso tenga su Herrera..., pero lo que más importa es que tenga sus lectores, sin anotaciones» (Soria Olmedo, 1992: 567).

\section{PRIMEROS LIBROS}

Con toda nitidez se distinguen tres fases en la poesía de Salinas: las primeras obras, Presagios, Seguro azar y Fábula y signo, salen entre 1924 y 1931 y forman un grupo. Una segunda etapa está centrada en el tema amoroso con La voz a ti debida, Razón de amor, y Largo lamento. A ellos se añaden los libros publicados después de 1940: $E l$ Contemplado, Todo más claro y Confianza. Varios poetas de su generación invitan a considerar la obra de Salinas en su conjunto. Así, Jorge Guillén sugiere comprobar que Salinas es Salinas a lo largo de toda su carrera. Del mismo modo la crítica ha solido destacar dentro de la evolución los caracteres que agavillan todo el conjunto, con particular referencia a los temas presentes en todas las trilogías (Palley, 1966; E. de Zuleta, 1971: 67 ss.; etc.). Han sido objeto de análisis - por ejemplo - la presencia del diálogo a lo largo de toda la obra (A. de Zubizarreta, 1969); las distintas preferencias dentro del versolibrismo, etc. Teniendo presente esta unidad, apuntaré aquí algunas notas de la lengua de Pedro Salinas refiriéndome a las tres etapas de su poesía.

Presagios contiene los poemas más breves en extensión de toda la obra del escritor ${ }^{3}$. Pese a las dependencias que mantiene con otros

3 Desde los 18 versos con que se presenta el poema típico de este libro inicial, las composiciones de Salinas se irán dilatando progresivamente hasta llegar a $E l$ Contemplado. Sólo Confianza retrocede en esta tendencia (I. Prat, 1983: 102). 
poetas (Bécquer, Juan Ramón, Unamuno, Machado) ${ }^{4}$, en los años que ha tardado en «forjar los eslabones» de Presagios Salinas ha ido tomando opciones que se habrán de mantener en toda su obra posterior: a la altura de 1914 y 1915 las cartas a Margarita Bonmatí testimonian su inclinación por el verso libre ${ }^{5}$. El joven Salinas entiende el significado de la renovación poética que vivía Francia: participa en la antología preparada por sus amigos Díez-Canedo y Fortún en $1913^{\circ}$; y desde las cartas dirigidas a Margarita, cuando es profesorlector en París, comenta su postura ante la renovación del lenguaje poético:

Te diré que efectivamente hay hoy en España como en Francia, una renovación de las letras. Mucho más réussi en Francia [...]. Aquí empieza a iniciarse una tendencia moderna que en poesía se ha de manifestar creo yo, por el verso-librismo, y que tiene un carácter marcadamente idealista, pero sin perder sus dotes de realidad. La poesía española de hoy ha llegado con Rubén Darío, con Juan Ramón Jiménez y Antonio Machado, a nobles cimas. Pero los poetas jóvenes ya no podemos seguir ese camino, y buscamos formas nuevas para nuestros pensamientos $(1984: 128)^{7}$.

Así pues, en Presagios es claro que, como a su admirado Verhaeren, la métrica tradicional se ha convertido en un traje demasiado estrecho. Todavía permanecen vagas asonancias, pero ha prescindido del aliño sonoro de bastantes recursos modernistas ${ }^{8}$. Queda, eso sí, la complacencia en suaves armonías vocálicas, rimas internas, y marcadas aliteraciones ${ }^{9}$ :

4 Alguno de ellos recordado aún en el «Prefacio» de Todo más claro.

5 «Creo... que he encontrado mi forma. Es, sí, verso libre. Hasta ahora en España no se han hecho apenas intentos de esa forma. Yo creo que es la que más conviene a mi espíritu y al mismo tiempo la que más se necesita cultivar en castellano» (Salinas, 1984: 134).

6 Vid. ahora Díez-Canedo y Fortún (1994).

7 Más tarde valora así el alcance de lo que supuso medio siglo (1900-1935) de literatura en lengua castellana señalada por «el signo del lirismo»: "Una transformación del lenguaje poético, no conocida en la poesía española desde el gongorismo, y de mucho más empuje y alcance, ya que afecta a todos los conceptos hereditarios y admitidos sobre limitaciones estéticas, moldes métricos y convenciones idiomáticas» (Salinas, 1983: III, 228).

8 I. Paraíso (1985: 234) encuentra dos tendencias métricas en el libro: una, hacia formas isométricas con base en el octosílabo, con asonancia única o múltiple; y otra tendencia - menos frecuentada - hacia formas heterométricas que da como resultado silvas libres híbridas, con mezcla de metros impares y pares, y con asonancias dispersas.

González Muela (1954: 60) ve tanto en Valéry como en la generación del 27 el interés por la eufonía del diptongo y sobre todo, por ritmo fundamental en toda la composición. 
Y sólo así se están quietas, enclavijadas,

asidas ansia con ansia

y deseo con deseo (Salinas, 1981: $55^{10}$ ).

El poeta se inclina decididamente por un léxico sencillo: ni el color, ni el exotismo, ni el brillo cegador del modernismo se encontrarán aquí. Agua, labio, beso, mano, mar, mundo, noche, alma, nombre, ojo, luz, cuerpo, vida... son todos sustantivos que, ya desde Presagios, irán sumando muchas apariciones a lo largo de su obra. Junto al gusto por los significantes de tradición poética, que comparte con los poetas de la generación del 27 - tal como vio González Muela (1954: 62)(silbo, claridades, nostalgia), se da en Salinas el empleo de expresiones coloquiales, metáforas desgastadas por el uso y repeticiones de la lengua oral, algunas veces con un marcado tono humorístico o con fines de contraste: «sentar la cabeza», «va a su negocio», «corre que te correrás», «nada más... nada menos», «otra vez será», etc. No se puede rechazar ningún vocablo ${ }^{11}$, porque - como decía Jorge Guillén- «la poesía no requiere ningún especial lenguaje poético»; «no hay más que lenguaje de poema: palabras situadas en un conjunto» (1983: 195). Caben pues palabras como anarquista o casquivana, voces que se presentan en coordinaciones un tanto sorprendentes: «La niña estaba callada,/ toda en nostalgias románticas/...Y mamá que no tenía/ ideales ni reúma», o en las típicas enumeraciones de Salinas («cuna, caballo, avión/ y servicio militar») ${ }^{12}$.

Un poeta de su generación, Alberti, subrayaba en la primera obra de don Pedro el realismo, la nota madrileña y populachera clavada en un fondo de poemas de tono íntimo, contenido, sofrenado. «Castellana al fin, la lírica de Salinas mostró, desde un principio, una línea escueta, tensa, sin halagos externos, cuya columna va por dentro, sosteniendo, esqueleto seguro, la carne verdadera que la envuelve» (1983: 324).

La sintaxis de Presagios exhibe asimismo notable sencillez y agilidad, con un amplio uso de la oración simple y de la yuxtaposición para traducir diferentes tipos de dependencias sintácticas. Puede tratarse de grupos oracionales de sentido adversativo seguidos de negación: «No

\footnotetext{
10 En adelante todas las citas se harán por esta edición.

11 Es en Pedro Salinas característica constante: célico junto a escombrera leemos en Todo más claro.

12 Claudio Guillén (1991:75) recuerda la actitud ambivalente de Salinas, entre la adhesión y la desconfianza, ante el lenguaje, ante los «nombres».
} 
de cantera nacida,/ ni de piedra ni de hierro,/ no trabajada por manos, hecha del alma» (70); o de relaciones adverbiales: «Estos dulces vocablos con que me estás hablando/ no los entiendo, paisaje,/ no son los míos» (74). En muchas ocasiones encontramos acumulaciones de frases; por ejemplo, las imágenes adquieren habitualmente la forma de frases bimembres, con dos miembros yuxtapuestos: «Agua en la noche, serpiente indecisa,/ silbo menor y rumbo ignorado» (54); «frente a frente tierra y cielo,/ paralelismo de espejos» (84); « Facilidad, mala novia!» (91). Aunque no faltan las oraciones con el verbo copulativo explícito: «El árbol...es un chiquillo/ que lloraba por tener/ vestido nuevo» (68); «libro mío/... eres un frío mazo de papel blanco» (78). La omisión del verbo se corresponde con la descripción impresionista de algunos poemas. En el siguiente ejemplo también concurre la ausencia del artículo, que simplifica aún la construcción oracional:

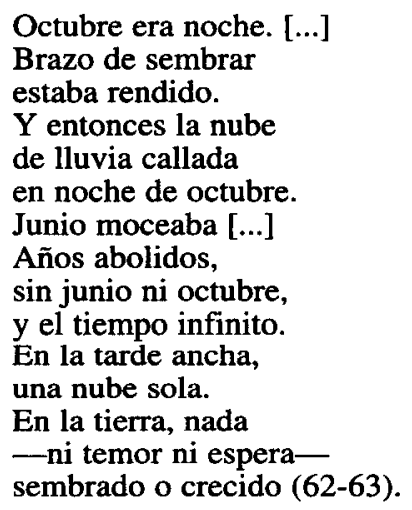

Los adjetivos se presentan con frecuencia en parejas: «cálida y áurea»; «virgen y sola», «alta y súbita», «tenue y vaga», «altos y difíciles», «áureos y tensos», «exacta e inaccesible», «redondo y fresco», «versátil y clara», «ansioso y torpe», «dura y seca»... Predomina en el estilo nominal de Salinas el adjetivo pospuesto. En varios poemas de Presagios el poeta quiere captar la realidad que se halla detrás de la apariencia, descifrar los engaños, disolver el incómodo movimiento de las cosas, tantas veces repetido, monótono. Entonces Salinas suele dirigir la palabra a objetos o abstracciones y en su diálogo surgen vocativos y aposiciones, frases sin verbo y nombres sin determinante que señalan las esencias perseguidas por el poeta: «Posesión de tu nombre,/ sola que tú permites,/ felicidad, alma sin cuerpo». Ocasionalmente la oración se dilata para reproducir la indagación del 
poeta, en la sombra - por ejemplo--: «Me define de modos muy distintos,/ es más ágil que yo y en tanto lucho/ por dar con el secreto del movimiento justo/ para mi verbo, ella se expresa bien, se alarga,/ se hace tenue y vaga como la noche exige/ o se precisa como verso de mármol/ si así lo quiere el sol» (85).

Son temas repetidos la nada, la ausencia, la percepción de los objetos. Suaves paralelismos, casi nunca mantenidos en largos espacios, y el uso aún tímido de la derivatio ponen de relieve los contrastes en la búsqueda del poeta (placer-dolor, brusco-lento, hoy-mañana, luz-oscuro...), y explicitan las paradojas: « ¡Soledad, soledad, tú me acompañas/ y de tu propia pena me liberas!/ Solo, quiero estar solo;/ [...] Y me destila las verdades dulces/ la divina mentira de estar solo» (65); «mano de ciego no es ciega» (55); «Y por eso la mato cada día/ entrándome en la casa, toda sombra sin sombras,/ asesino pueril y Caín de burla» (85). Surgen así repeticiones; de ellas y de la rima procede la armonía de la composición que a veces exhibe una estructura circular (poema $\mathrm{n}^{\circ} 1$ ). A los poemas de Presagios les corresponde una oración breve, poco inclinada al hipérbaton (salvo en los sonetos de libro), contenida en metros predominantemente cortos y con suaves encabalgamientos. Parecen notas destacadas la extensión de los sintagmas bimembres y el uso todavía reducido de la enumeración.

Guillén vio cómo Seguro azar anuncia desde su título más sutilezas de intelecto y sentimiento. En efecto, la metáfora, la sinécdoque, la personificación conocen ahora un uso más amplio. Ahora se acumulan para conseguir efectos variados (V. Cabrera, 1975: 115): contrastes, equívocos, ironía, humor... Salinas rechaza la definición de la metáfora como comparación lógica entre dos ideas y en su lugar levanta el concepto de creación:

Una metáfora es como la expresión de lo que el poeta piensa del mundo y de las cosas [...]. La metáfora es un acto intuitivo por el cual el poeta se apodera de una realidad nueva, en la cual quedan absorbidas las dos realidades anteriores. Porque la metáfora tiene eso de capital: al comparar dos cosas, destruirlas; pero no destruirlas para que no sean, sino para que de ellas salga una tercera realidad nueva. De manera que la metáfora, como la poesía, para mí es una creación de nuevas realidades» (Salinas, 1983: I, 122)

Con imágenes visuales, que implican a menudo personificaciones, el poeta continúa su particular búsqueda de lo escondido o de impresiones sensoriales, y se propone captar muchos instantes de tránsito: cambio de un momento a otro momento, el paso del día a la noche, de 
la percepción a la ausencia... Las imágenes de la ciudad y los objetos del mundo moderno cobran vida en Seguro azar y en Fábula y signo, y quedan aludidos mediante series de sustantivos en aposición: «artificial princesa, amada eléctrica»; «maniquí, creación de primavera».

A la escisión estrófica de los poemas contenidos en este libro de 1929 le corresponde una mayor fragmentación de la sintaxis: hay más guiones, más pausas que en Presagios. Las series binarias se convierten ahora en abundantes trimembraciones. Las enumeraciones que despliegan ya casi todos los poemas, se ponen al servicio de la descripción («Parecen nubes. Veleras,/ voladoras, lino, pluma,/ al viento, al mar, a las ondas/ — parecen el mar- del viento,/ al nido, al puerto, horizontes,/ certeras van como nubes» [108]); pero sirven también para desintegrar percepciones engañosas, para reflejar el caos, o para trazar el movimiento de las cosas ( $\ll \mathrm{Si}$ descansan sus guardas a los lados/ acero, prisa, ruido, corren» [130]).

El adjetivo se presenta igualmente en grupos de tres elementos, aunque no escasean las parejas: «ligerísismas, escurridizas, altas»; «fría, invencible, eterna»; «amarillo, verde, rojo»; «fragmentado, alegre, vivo»; «tersa, pulida, rosada»; «enormes, verdes, azules/ servicial, lisa, esquemática». Así pues, vemos que el poeta deja constancia en Seguro azar de su preferencia por las series de tres en las división de los poemas en estrofas, en las reiteraciones paralelísticas (poema «El mal invitado» [115]) y en los sintagmas nominales y adjetivos. Sin embargo, Salinas maneja acumulaciones de adjetivos sin ceder al adorno gratuito, sin implicarse en estimaciones subjetivas y ello porque predomina la posposición de los adjetivos y además éstos con frecuencia se refieren también al verbo ${ }^{13}$ : «El primer día de la creación/ humillado, pobre, vencido,/ se marchó a llorar a un rincón» (134); «En la calle hirviente, clara,/ a las doce en punto, sola/ una luz artificiall olvidadal en una ventana alta/ - sólo yo la veo-flor/ amarilla y torpe, errata/ de las doce y de lo gris» (147). De los adjetivos cabe destacar asimismo el frecuente uso del grado superlativo, que sólo había aparecido tímidamente con anterioridad y que desde aquí se hará constante en la lengua de Salinas: blanquísimo, fugacísimo, brevísimo, clarísima, ligerísimas...

13 «Los adjetivos antepuestos representan nuestra manera de sentir las realidades del mundo». Mediante la abundancia de adjetivos antepuestos conocemos la manera de sentir las realidades del mundo que tiene el poeta, sus juicios de valor (Salinas, 1983: III, 131). 
Domina, como en los primeros poemas publicados, el estilo nominal visible en estos versos de «El zumo»: «Pero el secreto defiende,/ invisible amarga almendra,/ su mañana, su secreto/ mayor, dentro. / Lo que da son disimulos,/ redondez, color, rebrillo,/ solución fácil, naranja,/ a la mirada y al viento (112). Si bien las oraciones rápidas y breves son muy abundantes, Salinas también es capaz de manejar la estructura sintáctica de modo que las oraciones se dilaten, que las palabras se desplacen dentro del poema según sus intereses. Así, retrasan su aparición nombres y verbos para sugerir el enigma de una imagen, el movimiento o la aparición esperada de algo:

\author{
Verlo tanto \\ que esto que me queda ahora \\ clavado e inolvidable \\ como el más alto cantar, \\ esto, que nunca se olvidará \\ en mí porque fue del tiempo, \\ de tan mío, de tan visto, \\ de tan descifrado, fuera, \\ eternidad, lo olvidado (115).
}

Los recursos fónicos se hacen más perceptibles que en Presagios: rimas internas, paronomasias, aliteraciones... Estas últimas se encuentran con gran facilidad: «Yo buscco por donde estaban./ Desbrozadora de sombras/ tantea la mano. A oscuras / vagas huellas sigue el ansia» (124); «En febrero me rindo;/ a su núbil imperio/ —el pecho apunta apenas-/ resistencias ahorro» (140)... Feal Deibe (1965: 39-42) comenta otro procedimiento: el interesante uso del contraste entre vocales cerradas extremas y abiertas que colabora en la expresión de otra lucha de conceptos.

Junto a las imágenes visuales y conceptuales, que tanto han hecho hablar a los críticos de la relación de Salinas y las vanguardias (por ejemplo, C. Maurer, 1991: 147), creo que interesa destacar de Seguro azar la insistencia en los grupos ternarios y las armonías fónicas, sin olvidar el uso de la sinestesia que también desde este libro será una constante en la lengua del autor: «seguridades dulces»; «días y noches blandos»; «miedo frío»; «voces redondas»; «silencio liso», etc. ${ }^{14}$.

$14 \varkappa_{i}$ Qué verdad es la sinestesia!... la sensación que no viene de un solo sentido, sino de varios, y de una síntesis interior de los sentidos. Así me explico lo que mis ojos hacen, al traerme al alma un aire» (Soria Olmedo, 1996: 164). 
En Fábula y signo, de 1931, aumenta la galería de objetos del mundo moderno traídos a la vida ${ }^{15}$-entre recuerdos de lo antiguo, entre referencias mitológicas - con perfiles precisos: exactitud de medidas, de tiempos, de formas, o precisión de cantidades. Así se dibuja, por ejemplo, el Escorial («seiscientas doce ventanas»; «Tres siglos tiene; tendrál veinte, ciento») ${ }^{16}$. Un ejemplo más:

\author{
Se ve que es una hora \\ en que no pasó nada más que ella: \\ sus sesenta minutos \\ lentísimos, sesenta besos largos, \\ inocentes \\ en la mejilla tierna de una tarde \\ de un setiembre cualquiera, no sé dónde (166).
}

En este poema llamado «reló pintado» la lentitud que expresa está significada por la dilatación de la oración con repeticiones, y encabalgamientos, que en este libro conocen un empleo recurrente al servicio del sentido. De este modo la sintaxis funciona como símbolo, por la relación motivada que liga el signo con la realidad poética. Las enumeraciones se apoderan del discurso, aunque no se halla tan desintegrado como en Seguro azar.

Junto al uso del superlativo se señala otro procedimiento de intensificación permanente en toda su obra: las construcciones consecutivas como: «tan sin pareja», «tan sin pruebas», «tan en silencio», «tan de flores», «tan de color»...

Los últimos poemas de Fábula y signo enlazan de manera especial con el ciclo amoroso, por su contenido y su diseño elocutivo. Basta recordar las derivaciones del poema titulado «Salvación»; las repeticiones (anáforas y epíforas) de «Los adioses»; los juegos de contrarios ( Juntos ya siempre por la despedida,/ inseparables/ al borde mismo - adiós- del separarse») o la insistencia en los pronombres (en el

15 Las máquinas son para Salinas fuentes de bellezas nunca previstas. La poesía no podía sino sentirse «fatalmente seducida, antes o después por este aspecto del mundo que tiene tanto derecho a ser tema estético como la rosa, la gacela o el sentimiento de la muerte» (1983: I, 285).

16 Y el jardín de los frailes («Enorme/ deber de la piedra gris/... Se te quiebran las rectas,/ los planos se te arquean»); la estación («Pregonada ciudad, villa en el aire,/... tu ausencia con tres sílabas/... ¡Qué ciudad temblorosa de un minuto...!»); la máquina de escribir («a las treinta, eternas ninfas»); el taxi, el teléfono (nos separaban diez ríos,/ tres idiomas, dos fronteras:/ ... Me llegabas,/ en alambre, por tu voz»), etc. 
poema «Pregunta más allá»). Si bien es cierto que la epanadiplosis y otras figuras de repetición recorrían todo libro: «abril al treinta de abril»; «piedra, con alma de piedra»; «quieto en el agua quieta»...

\title{
TRILOGÍA SOBRE EL AMOR
}

Con La voz a ti debida se inicia otra etapa en la poesía de Salinas. No porque el tema del amor no haya aparecido. Además, aunque en este momento se reduce la variedad de los asuntos implicados, el tema consiste en definitiva en una nueva búsqueda ${ }^{17}$. Algunos elementos formales varían: el diálogo consigo mismo se reduce al tiempo que el heptasílabo se convierte en el metro dominante $(65,2 \%)$. El metro menor, ahora enriquecido con registros precisos y delicados (Darmangeat, 1969: 129), permite la comunicación de la experiencia amorosa vivida desde el presente. El poeta indaga hasta dar con la expresión rigurosa y para ello acude tanto a las figuras troqueladas desde la tradición petrarquista ${ }^{18}$, como a las novedades en los ritmos y hasta en el léxico. No escasea la sustantivación de adverbios, de sintagmas preposicionales, etc. («la apenas siendo»; «se desprendió del quiero»; «tropezando en acasos»; «repetir lo nunca igual»), ni el recurso, tantas veces citado, a creación de palabras: trasnoche, trasamor...

Las oraciones bien pueden ser ágiles ( «Y súbita, de pronto,/ porque sí, la alegría./ Sola, porque ella quiso,/ vino»), con la urgencia del imperativo o del presente de subjuntivo con valor optativo; o bien pueden reflejar una busca que se pone difícil:

\author{
¿Y si hubiese \\ otra luz más en el mundo \\ para sacarles a ellas, \\ cuerpos ya de sombra, otras \\ sombras más últimas, sueltas \\ de color, de forma, libres \\ de sospecha de materia; \\ y que no se viesen ya \\ y que hubiera que buscarlas
}

17 Como señala C. Guillén, (1991: 81) interrogación, afán y búsqueda confieren una indiscutible unidad a la tan diversa obra de Salinas. Unidad estética, claro está, y unidad moral.

18 Vid. M. Escartín (1993), y las notas de esta prof. en su ed. de La voz (1996). 
a ciegas, por entre cielos, desdeñando ya las otras, sin escuchar ya las voces de esos cuerpos disfrazados de sombras, sobre la tierra?» (328).

De varias maneras ha considerado la crítica las fases y los estilos narrativos dentro de la unidad de este libro subtitulado «Poema», pero tanto en el gozo del encuentro y en la búsqueda de la realidad de la amada, como en el sobresalto de los temores puede hablarse de un enorme dinamismo de las imágenes y de las enumeraciones (Spitzer, 1974), de los grupos binarios y de las trimembraciones:

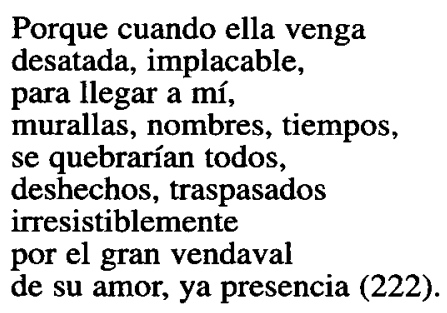

Su discurso poético registra aquí la máxima concentración de figuras fónicas y repetitivas (G. Morelli, 1992), aliadas firmemente con las paradojas (Spitzer, 1974: 206). Sólo destacaré que entre las numerosas amplificaciones, con las que se tejen los juegos conceptistas y que traducen prisa e intensificación, se encuentra la derivatio, recurso que ya no abandonará jamás la lengua de Salinas: «te mudas... en tu propia mudanza»; «alegría con que te alegraras»; «amor del que tú te enamorases»; «dolor,... me dueles»...

Razón de amor continúa en muchos sentidos el adorno elocutivo de La voz, con su furia enumerativa, con las múltiples repeticiones que sirven a la precesión, a la búsqueda de esencias. Aliteraciones y sinestesias hablan del amor sensual en un discurso donde se ha instalado la argmentación y el análisis para analizar un amor ya vivido. El verso entonces se alarga, la oración se ensancha para acoger las numerosas contradicciones que entraña querer «justificar la irracionalidad del amor» (M. Escartín-Salinas, 1996: 35): 
Nos dice que no y que no, pero hay que seguir queriéndolo: porque el no tiene un revés, quien lo dice no lo sabe, y siguiendo en el querer los dos se lo encontraremos. Hoy, mañana, junto al nunca... (357)

Metáforas, comparaciones y personificaciones siguen presentes, mientras que los adjetivos en grupos ternarios apenas se dan. Tanto en La voz como en Razón de amor Salinas parece haber encontrado su madurez expresiva, su posición entre la tradición y la modernidad: el poeta «se emancipa» de la comunidad linguiística con creaciones propias (más última; tuyamente; desensueña; transvivirse; traspresencia...) y hace saltar los límites de un vocabulario estrictamente poético. Al lado de los recursos que le son más peculiares, como juegos de contrarios enredados en quiasmos, imágenes o sinestesias, Salinas acude aquí, y más en los libros del exilio, a la voz de otros poetas. Así, sólo en el poema $\mathrm{n}^{\circ} 14$ de Razón de amor leemos: «celo celeste»; «con las aguas de abril»; «¿En dónde están los pétalos?.../ Tiene que haber un cielo...», confirmando cómo entendía que literatura es secuencia ${ }^{19}$.

En los monólogos de Largo lamento una oración amplia vuelve a dominar la evocación del amor pasado. El autor, que había traducido en 1922 En busca del tiempo perdido, emplea un verso dilatado con un ritmo cercano a la prosa: «Yo te suplico que en futuras tardes/ de invierno alfombrados por olvidos,/ cuando tú en tu salón, tengas en una mano/ como vagos pretextos para vivir/ algunos poemas chinos ricamente encuadernados, / y en la otra el cigarrillo que nos sirve/ como de un simulacro/ del suicidio tantas veces al día/ concedas en tu erguida/ cabeza sola un minuto de audiencia,/ a la memoria de esa nuestra primer morada» (575-576).

El poeta sigue formulando su desengaño en los cauces habituales de juegos de contrarios: «Me lo siento en las manos,/ enormes fosas llenas de su falta./Está yacente: tumba le es mi pecho./ Me resuena en los pasos/ que van, como viviendo, hacia mi muerte»; combinados a veces

19 Las ideas expuestas acerca del lenguaje y del arte se extienden a su visión de los temas de la poesía: si el repertorio de los movimientos espirituales del hombre dice- no se ha acrecentado; cada uno de los sentimientos «se ha enriquecido inmensamente a fuerza de ser vivido por millones y millones de seres humanos. Son precisamente los poetas del amor y los héroes del amor los que han contribuido a que el sentimiento amoroso, siempre existente, sea hoy mucho más rico en matices, en horizontes y en profundidades» (Salinas, 1983: I, 281). 
con la sinestesia «quietud redonda»; «viento gris»; «rumor tierno», «luz tenebrosa y dura, luz sin sol»; «aire oscuro»; «primaveras redondas,/ cánticos que rebotan,/ elásticos». Pero resulta más habitual que, el desengaño y hasta los remordimientos se expresen en un tono conversacional más sosegado, falto de tensión sintáctica, donde tienen cabida muchas expresiones coloquiales: «cara a cara», «te hablo con absoluta claridad», «de par en par»... Al lado de las imágenes reiteradas de la sombra, la muerte, el agua, ya habituales en la lengua de Salinas, la comparación cobra en Largo lamento un protagonismo absoluto. El desarrollo de la comparación se adapta, mejor que la metáfora, a la fluencia del recuerdo y al ritmo del arte mayor:

\author{
Estoy triste esta noche \\ porque soy lo que soy, como los árboles \\ que esclavizados a su tronco sufren \\ tanto a los lados de las carreteras (472).
}

Paralelismos y anáforas constantes contribuyen a la plasmación de ese tempo lento característico de los poemas, sin embargo hay figuras de repetición mucho más frecuentes: poliptoton, derivatio y reduplicación ${ }^{20}$. Las recurrencias léxicas, cercanas a la lengua oral ${ }^{21}$ pueden tener un valor intensivo ( «manos, muchas manos», «quieto, muy quieto»); también traducen movimientos repetidos o ritmos pausados: «entre sorbo y sorbo», «las he tenido entre las mías,/ un año y otro año y otro año», «pétalo a pétalo», «uno por uno», «de siglo en siglo», «porque los llenan gota a gota,/ día a día»; o manifiestan la angustia del poeta: « ¿Y las alas, las alas?»; «Y busco y busco».

\title{
LOS LIBROS AMERICANOS
}

La última trilogía se abre con El Contemplado. Tema con variaciones, nuevo cambio en el sentido del diálogo y en la forma mé-

20 No faltan casos de anadiplosis y epanadiplosis: «¿Quieres, di, que vayamos por los años,/ los años del futuro, como cielos...?»; «cerrada estás, cerrada/ sobre ti misma»; «temblar, hace temblar».

21 El poeta suele reiterar una misma palabra tres veces (también cuatro y hasta seis veces), e inventa estructuras de repetición del tipo: «un crecer de amor y amor y amor/ dentro de amor»; «recordar, recordar sombras de sombras». 
trica ${ }^{22}$. Aunque continúa el protagonismo del endecasílabo, ahora recupera las asonancias marcadas de la primera época al tiempo que avanza el octosílabo. El libro, que comenzaba con unos versos de Cántico, transcurre con más recuerdos de la lengua (y de la métrica) de Guillén, de Bécquer, de Unamuno, de los místicos, de Góngora...; sin que falte la evocación de su propia obra: en juegos de palabras recurrentes, en los títulos utilizados dentro de su libros anteriores: «Presagio», «Salvación»... Junto a tan fuerte abrazo de la tradición, el poeta prosigue con los neologismos (entimismado, trocadero), aunque de sólo un nombre, dado al mar de Puerto Rico, se siente creador, de «el Contemplado» ( $«$ Desde que te llamo así,/por mi nombre»). Dentro de la gran sencillez de la sintaxis, el hipérbaton cumple ahora fines rítmicos antes encomendados a los sintagmas bimembres, enumeraciones o encabalgamientos. En múltiples oraciones breves el retraso del verbo colabora con la alternancia de medidas y rimas para reproducir el movimiento del mar: «Al célico sosiego otro marino/sosiego le contesta./Las últimas congojas de la ola/playa se las consuela» (627). Aunque las imágenes referidas al color, a la luz de «el Contemplado» son numerosas, se dejan sentir aún más al lado de los remedos del hipérbaton gongorino en «textoeje» del libro —en expresión de I. Prat (1983)—, en la variación VII («Las ínsulas extrañas»).

El libro carece de las violentas antítesis, y de tanta negación sostenida durante amplios fragmentos como se leía en el ciclo anterior; si bien es verdad que existe una parte del libro «más conceptual», donde caben todos estos recursos, según las diferencias que la crítica ha establecido (F.J. Díez de Revenga, Salinas, 1996: 26-27). Las repeticiones ahora no reflejan el desasosiego o la frustración, sino la constante contemplación del poeta y de los hombres («Míralo aunque se haya ido./Visto o no visto, contémplalo./ $\mathrm{El}$ mirar no tiene fin» [621]; «QQué antigua es esa mirada,/ en mi presente mirando!» [647]). Y sobre todo hay repetición para la intensidad del azul, de la luz... ( «Van a su cielo:/ su cielo el mar, que azul, cielo duplica»; «la arena ¿quién la ha alisado,/ tan lisa, tan lisa» [629]); para el movimiento del mar ( CCada vez tu obra se acerca/ ola a ola,/ más y más a sus modelos» [638]; «onda a onda»; «curvas, más curvas»). Idéntico sentido adquieren muchas aliteraciones.

22 Paso de la poesía debida al tú de la mujer amada, a la poesía vertida hacia un humanizador Más allá del hombre (Marichal, 1974: 29). 
Los poemas urbanos de Todo más claro, extensos y de metro dilatado (domina el endecasílabo), contrastan en cierto modo con los otros libros del ciclo final. En la última trilogía la lengua literaria de Salinas expande la derivación y todo tipo de reiteraciones léxicas con más insistencia que nunca, mientras que el uso de adjetivos agrupados casi desapararece. En Todo más claro las recurrencias de lexemas y de significados son signo de la angustia del hombre que se siente «al mismo borde del borde». Salinas lo dice en su «Prefacio»: «Porque las angustias arremeten por muchos lados. Y ahí están las mías, en este librito, para el que no se quiera cerrar a verlas: so capa de anécdota y por rodeos callejeros y alusivos en ciertos poemas de ciudad» (655). El movimiento descrito con las reiteraciones es muy diferente del que exhibirá Confianza, porque el «sino de la vida es lo incompleto»; «porque la vida, dicen, dicen, dicen, / es eso, es un correr, sin paradero»:

\author{
Perdido estoy, mi sangre \\ quiere que siga siendo, \\ escoge, contra mi sangre \\ quiere que siga siendo, \\ escoge, contra mi, contra vosotros, \\ la gran mortalidad: el movimiento (150).
}

Ahora representa los conflictos del hombre eligiendo de entre las fases de la realidad, las referidas a lo cultural, a lo fabril, a lo social ${ }^{23}$. La escisión del ser humano, lo absurdo de sus movimientos, lo limitado de sus elecciones se plasman en las múltiples antítesis que comenzaban en el «Prefacio» ${ }^{24}$, en acumulaciones y en las poderosas imágenes.

En los poemas de Confianza, escritos durante los años 40 , no cede la «inquietud interrogativa». En el componente léxico no faltará tampoco ninguno de los rasgos característicos de Salinas: el uso de superlativos absolutos, nominalizaciones, expresiones coloquiales. Paralelismos sostenidos, frecuentes anáforas y estribillos,

23 «Hoy la realidad está haciendo gestos y señas a los poetas desde el sector de lo social, de lo colectivo, pero de una forma de vida colectiva que no es la aventura heroica» (Salinas, 1983: I, 286-287).

24 «Conozco la gran paradoja: que en los cubículos de los laboratorios, celebrados templos del progreso, se elabora del modo más racional la técnica del más definitivo regreso del ser humano: la vuelta del ser al no ser» (655). 
organizan la armonía de un discurso en el que surgen a menudo aliteraciones: «Trino más trino, el ave su victoria/ proclama en trono verde./ De triunfos embriagado, por fin deja/ que un vuelo se lo lleve» (817).

Algunas notas traen a la memoria la sintaxis ágil o la variedad de temas de la primera etapa de Salinas; no obstante, aunque vuelven las formas de bases octosílabas y las composiciones se hacen más breves, pueden apuntarse diferencias con respecto a la lengua de los primeros libros: por ejemplo, los adjetivos apenas se presentan en tríos, y del mismo modo, escasean las parejas de calificativos. Varios poemas se refieren al tema de la creación poética, y en casi todos están presentes los elementos de la naturaleza: agua, bosque, río, pájaro, nube... Tratan, una vez más, de la búsqueda, del contraste entre lo aparente y lo real; ahora con más detalle de lo único y lo diverso, de lo plural y la unidad. Todas estas oposiciones se plasman en antítesis: «¿Nada quieto y todo en calma»; «Ni goce ni pena,/ni cielo ni tierra, / ni arriba ni abajo,/ ni vida ni muerte, nada:/ sólo el amor, sólo amando» (805); «Y si ayer vapor la vi,/ en mi mano está su peso» (789). Es claro que los recursos no son nuevos, pero en estos casos se trata de contrastes que han excluido toda violencia, de enumeraciones que no muestran el caos («anda o vibra o goza o canta»; «sale, luce, esplende, alegra»). El movimiento de las cosas ya no resulta perturbadoramente monótono, como en Presagios; se trata de un movimiento seguro, lento, «redondo» ${ }^{25}$ : «Y aquella deriva lenta,/ por los anchos firmamentos, en suave puerto termina: en la calma de unos pétalos» (788); «Un mundo rueda, tranquilo./ ¡Qué redondez tan perfecta!» (825). Cada metamorfosis pausada se contempla desde un presente ( $\ll \mathrm{Ni}$ recuerdos ni presagios:/ sólo el presente, cantando» — dicen los primeros versos del poema titulado «Presente simple»-), y mira a un futuro pleno de confianza:

Si no pasa nada, nada,

$y$ un presente se hace eterno,

vivirá la gota clara

muchas horas, horas largas,

ya sin horas, tiempos, siglos (814).

25 Bien dibujado en quiasmos («pone y quita, quita y pone»; «muchas horas, horas largas») y en las rimas. 
Además del uso de los tiempos verbales, el cauce de expresión de todo ello lo encuentra el poeta en los recuerdos de Bécquer: «Volverán agua y amor»; «Mientras haya/ lo que hubo ayer, lo que hay hoy,/ lo que venga». El «sentido de inminencia» que preside muchas de estas composiciones (E. de Zuleta, 1971: 69), la calma en la que «el mundo se mantiene rodando» se consigue con las múltiples reiteraciones y derivaciones: «El rosa, rosa tras rosa,/ disfraz y nuevo disfraz/ se prueba, de tallo en tallo/ buscando el rosa verdad» (818); «Benditos ojos, los ojos/ que hogaño este abril me dan./ Pero que abril me abrilea/ si pienso en ellos, colores,/ que están detrás» (802).

Así pues, parte del aderezo retórico ya conocido cobra ahora nuevo sentido expresivo. En Confianza, como en etapas iniciales, Salinas maneja un mínimo de recursos poéticos, su lengua se hace concentrada, precisa; sin embargo acrecienta las repeticiones de lexemas de manera parecida a los libros del ciclo amoroso. Semejanza parcial, puesto que ahora no sirven al juego de conceptos. En todas las variaciones de forma y de temas, desde la primera trilogía a la depurada composición de «Cero» (A. Soria, 1992: 321-322), hay siempre «arte de la poesía» —como decía Claudio Guillén (1983: 186) — «pero ningún huero formalismo. Claro que el semiignorante de hoy llama... formalismo a la plenitud de una forma bien trabajada, es decir cuidadosamente ajustada a su contenido».

\section{Referencias bibliográficas}

AlBerTI, R. (1983). La arboleda perdida. Barcelona: Seix Barral.

CABrera, V. (1975). Tres poetas a la luz de la metáfora: Salinas, Aleixandre y Guillén. Madrid: Gredos.

Darmangeat, P. (1969). Antonio Machado. Pedro Salinas. Jorge Guillén. Madrid: Insula.

Diego, G. (1991). Antología de Gerardo Diego. Poesía española contemporánea. Madrid: Taurus.

DíEz-CAnedo, E. y ForTun, F. (1994). La poesía francesa moderna (1913).

Gijón: Universos.

ESCARTín, M. (1993). «El uso de los tópicos literarios en la obra poética de

P. Salinas». Signo y memoria: ensayos sobre Pedro Salinas, 135-157.

Madrid: Pliegos.

Feal Deibe, C. $\left(1983^{3}\right)$. Lenguaje y poesía. Madrid: Alianza.

- (1965). La poesía de Pedro Salinas. Madrid: Gredos.

González Muela, J. (1954). El lenguaje poético en la generación

Guillén-Lorca. Madrid: Ínsula. 
GuILlÉN, J. (1983³). Lenguaje y poesía. Madrid: Alianza.

GuILlÉN, C. (1991). «Salinas en verso, Salinas en prosa». Revista de Occidente 126, 73-90.

Marichal, J. (1976). Tres voces de Pedro Salinas. Madrid: Josefina Betancor.

MAURER, C. (1991). «Salinas y las cosas: tradición y vanguardia». Revista de Occidente 126, 137-150.

Palley, J. (1966). La luz no usada. La poesía de Pedro Salinas. México: Andrea.

PARAíso, I. (1985). El verso libre hispánico. Madrid: Gredos.

PRAT, I. (1983). Estudios sobre poesía contemporánea. Madrid: Taurus.

Salinas, P. (1981). Poesias completas. Barcelona: Seix Barral.

- (1983). Ensayos completos. Madrid: Taurus, 3 vols.

- (1984). Cartas de amor a Margarita, 1912-1915. Madrid: Alianza.

- (1984²). El defensor. Madrid: Alianza Tres.

- (1996). La voz a ti debida. Razón de amor. Largo lamento, M. Escartín (ed.). Madrid: Cátedra.

- (1996). El Contemplado. Todo más claro y otros poemas, F.J. Díez de Revenga (ed.). Madrid: Castalia.

SORIA Olmedo, A. (ed.) (1992). P. Salinas / J. Guillén, Correspondencia (1923-1951). Barcelona: Tusquets.

- (ed.) (1996). Cartas de viaje (1912-1951). Valencia: Pre-textos.

SPITZER, L. $\left(1974^{2}\right)$. Lingüística e historia literaria. Madrid: Gredos.

Zubizarreta, A. de (1969). Pedro Salinas: el diálogo creador. Madrid: Gredos.

Zuleta, E. de (1971). Cinco poetas españoles. Madrid: Gredos. 